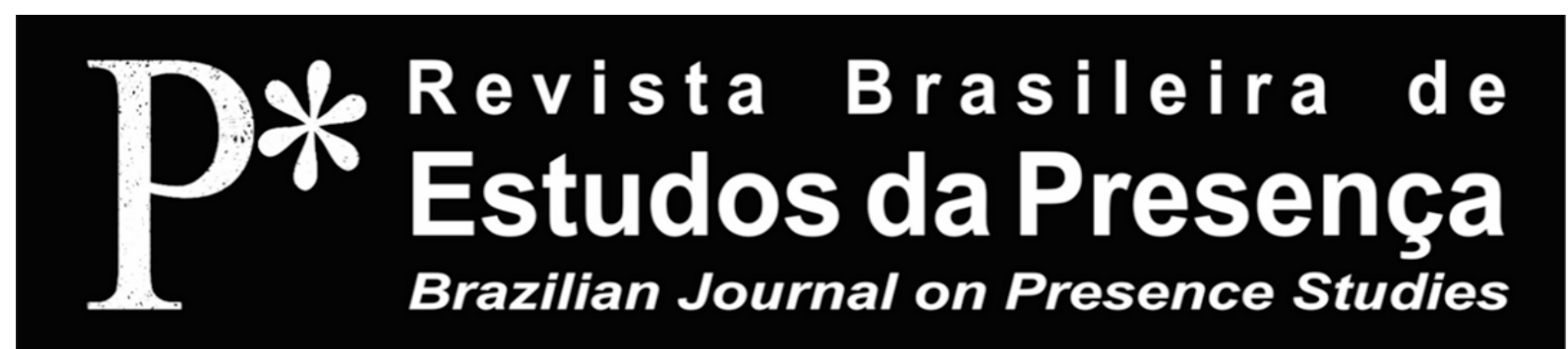

PROCESSOS DE CRIAÇÃO

E-ISSN 2237-2660

\title{
De Registros a Reflexões sobre - Corpo em Processo de Criação
}

\author{
Mônica Medeiros Ribeiro' \\ 'Universidade Federal de Minas Gerais - UFMG, Belo Horizonte/MG, Brasil
}

RESUMO - De Registros a Reflexóes sobre o Corpo em Processo de Criação - O artigo apresenta uma reflexão sobre o corpo por meio do estudo dos registros de movimento do processo de criação do espetáculo Aldebaran, do Grupo Oficcina Multimédia. Com o objetivo de pensar o corpo, realizou-se observação inventiva, leitura corpórea de desenhos de movimento e revisão da literatura. Discute-se os registros como instâncias mnemônicas performativas que viabilizam ressonâncias corpóreas entre o estudioso do processo e a imagem do movimento. $\mathrm{O}$ corpo em ressonância apresenta-se como condição para interaçóes poéticas de constituição da cena de dança e teatro, podendo a ressonância ser considerada como operador corpóreo da fruição artística e práticas de alteridade.

Palavras-chave: Corpo. Processo de criaçáo. Registro. Ressonância.

ABSTRACT - From Registers to Reflections on the Body in Process of Creation - The article presents a reflection on the body through the study of movement registers in the creation process of the show Aldebaran, by Grupo Oficcina Multimédia. Considering the body as the focus, an inventive observation, corporeal reading of movement drawings and a literature review were undertaken. Movement registers are discussed as performative mnemonic instances that enable corporeal resonances between the scholar of the process and the images of the movements. The body in resonance is shown as a condition for poetic interactions in scene constitution in dance and theater, and resonance is considered as a corporeal operator of artistic fruition and alterity practices.

Keywords: Body. Process of creation. Register. Resonance.

RÉSUMÉ - Des Enregistrements aux Réflexions sur le Corps en Cours de Création - L'article propose une réflexion sur le corps à travers l'étude des enregistrements de mouvement du processus de création du espetacle Aldebaran, du Grupo Oficcina Multimédia. Afin de penser au corps, de faire une observation inventive, une lecture corporelle de dessins de mouvement et de réaliser une étude de la littérature correspondante. Les enregistrements sont discutés comme des instances mnémoniques performatives qui permettent des résonances corporelles entre le chercheur du processus et l'image du mouvement.Le corps en résonance se présente comme une condition pour des interactions poétiques qui font partie de la scène de la danse et du théâtre, et la résonance peut être considérée comme un opérateur corporel de jouissance artistique et de pratiques de l'altérité. Mots-clés: Corps. Processus de Création. Enregistrement. Résonance. 


\section{Introduçáo}

Processos de criaçấo deixam rastros para além das memórias dos sujeitos neles envolvidos. Podemos identificá-los, especialmente, nos registros de processos de criaçáa feitos em diários de bordo, cadernos de processo, cadernos e livros de artista que acompanham criadores de diferentes linguagens artísticas, tais como literatura, música, artes visuais, teatro, dança. Mobilizada pelo desejo de desenvolver uma reflexão sobre o corpo cênico a partir dos rastros do processo de criação, tenho estudado as ações do artista da cena registradas sob a forma de desenho, letra, rasura.

Apresento neste texto uma reflexão sobre a relação entre registros de açóes, em cadernos de processo, e pensamentos sobre o corpo, como parte dos resultados da pesquisa $O$ corpo em processo: a performatividade dos registros na gênese da cena ${ }^{1}$. Essa investigaçáo iniciou-se com as seguintes questôes: quando o corpo em estado de criaçáo é registrado, como esse registro alcança um estado afectivo com potência para gerar outras açóes cênicas? $O$ que podemos dizer sobre o corpo a partir do estudo de desenhos de movimento originados em processos de criaçáo? Compartilho a seguir a reflexão fundamentada no estudo crítico-interpretativo dos desenhos de movimento registrados nos cadernos de processo do espetáculo Aldebaran $^{2}$, da diretora teatral e musicista Ione de Medeiros $^{3}$, que foram experimentados corporalmente, por meio de improvisaçóes, com o objetivo de pensar o corpo em processo de criação.

Importa ressaltar que compreendemos o movimento dançado pelo artista da cena como ação no sentido proposto por Grotowski (1993). Esse autor diferencia ação e movimento ao pontuar que a açáo está carregada de intencionalidade e é realizada com objetivo. Para esta reflexão, a ideia de movimento não será tomada como um conjunto de açóes reflexas e, muito menos, como simples execuçáo de um plano, mas sim como o resultado de uma comparação entre memória e predição das consequências da ação por intermédio da percepção (Berthoz, 2000). Importa também ressaltar que os registros estudados, documentos de processo, foram empreendidos durante o processo de criaçáo do espetáculo, enquanto o que apresento neste artigo refere-se ao processo da pesquisa realizada. Portanto, o processo de criação 
de movimentos foi estudado por meio dos registros de movimento que geraram um novo processo de experimentaçáo corporal, como se verá a seguir.

O processo de criaçáo foi compreendido como espaço-tempo para invençáo de novos movimentos na sua dimensão de experimentaçáo, o que implica na liberdade de escolhas entrelaçada ao repertório da pesquisadora/improvisadora. Dessa maneira, a criação de movimentos não foi realizada com o objetivo de gerar resultados sob a forma de um novo espetáculo, por essa razão não há registros imagéticos desse processo. Ressalto ainda que estar em processo de criação corporal, a partir do estudo dos registros em cadernos de processo, foi o que possibilitou pensar sobre estados do corpo no âmbito da experimentação artística. Desse modo, dois processos de criação se entrecruzaram mediante o estudo dos registros de movimento: o processo de criação do espetáculo de Aldebaran - que propiciou os desenhos de movimento - e o processo de criação como metodologia da própria pesquisa, experienciado por meio da improvisação corporal com o objetivo de se pensar sobre o corpo, movendo-o.

A ideia de registro, cuja origem etimológica latina - regestum - significa a retomada de algo que já aconteceu (re-gestum), se refere à transcriçáo e à escrita de informaçóes importantes. Considerei o registro como uma escrita plena de performatividade. Seu aspecto performativo está, justamente, em sua capacidade de transformação e de afecção do estudioso do processo de criação, como propóe Fischer-Lichte (2008) quando define performatividade. Segundo essa autora, a experiência performativa ultrapassa os limites hermenêuticos e gera uma espécie de infecção emocional no receptor-ativo. Assim, analogamente, o pesquisador de processos de criação que utiliza os registros como fonte investigativa prioritária poderia sofrer o impacto da potência performativa dos registros, sendo afetado pelos vestígios da obra. $\mathrm{O}$ próprio processo de documentação da criação em cadernos de processo pode ser visto como ato performativo que presentifica traços do percurso criativo.

Os registros foram tratados como instâncias mnemônicas performativas. Ao traçarmos um breve recorrido por alguns tipos de práticas ocidentais de registro de movimento dançado, é possível perceber que os modos de registros estáo intimamente associados a pensamentos sobre o corpo em movimento, sobre a dança. 
Por volta de 1700 , temos ciência daquela que tem sido considerada a primeira notaçáo coreográfica de Raoul Feuillet e Pierre Beauchamp ${ }^{4}$. Essa notação era feita por meio de desenhos - caracteres, figuras e sinais - que descreviam esquematicamente as direçôes do corpo e as ornamentaçóes de braços e pernas. O objetivo do ato de registrar era conservar a coreografia para posterior execuçáo, com vistas a exportar a dança barroca da corte de Luis XIV para toda a Europa (Moraes, 2019). Essa notaçáo ficou conhecida como Beauchamp-Feuillet Notation e foi referência em todo o século XVIII.

Ainda no século XVIII, Pierre Rameau acrescenta, ao registro de movimento dançado, movimentos de braços e tronco, aplicando-os em um manual da dança cortesã francesa, utilizando para isso figuras de corpos de homens e mulheres. A própria ideia de manual deixa transparecer que havia pouco espaço para invenção artística por parte daqueles que entrariam em contato com as notaçóes para nova encenaçáo coreográfica e dos que realizavam o ato de registrar.

Por volta de 1928, com Rudolf Laban, o registro de movimento condensa as chamadas leis de movimento em símbolos de alta abstraçáa. Nesse sistema, conhecido como Labannotation, interessava a essência do movimento inscrita no registro de acordo com um código que traduzia aspectos como: o sentido, a direção, a parte do corpo em movimento, a duração e a dinâmica. Um entremear de traços que intenta orientar o ato de dançar e denota outro modo de conceber a notaçáo de movimento na dança ao deixar evidente um espaço maior destinado ao intérprete do registro de dança e, também, àquele que pratica a documentação da dança. Algo muito importante estava, entáo, em relevo: a ideia de autoria, a autonomia do dançarino. Pois, ainda que fosse mantida a necessidade de reprodução da essência do movimento, constituído por suas qualidades - em relação ao espaço, tempo, peso e fluência -, a abstração conferia, de certo modo, maior liberdade na interpretação, favorecendo a assinatura pessoal do(a) dançarino(a) na execução da dança (Ribeiro; Teixeira, 2008) .

A abstração também marcou outros registros coreográficos, como os de Rudolf Benesh, gerando o sistema Benesh Notation (Benesh; Benesh, 1956). Em meados dos anos 1980, podemos perceber que essa abstraçáo caminhou rumo a maior liberdade de invenção do próprio registro, indo além da tendência anterior de representação fidedigna para a manutenção do movimento original. Anne Teresa de Keersmaeker e Jonnathan Burrows 
estáo entre os criadores europeus de dança, proeminentes nas décadas de 1980 e 1990, cujas notaçóes coreográficas demonstram uma ampliaçáo da potência performativa do ato de registrar e da consequente abertura do espaço para a interpretaçáo e para a criação pelo artista/performer de dança, a partir da leitura desses registros.

Os modos de registro de movimento dançado sofreram forte impacto das mídias digitais. Se, em meados do século XX, o vídeo fora protagônico, em pouco tempo os softwares somaram-se aos novos olhares sobre as anotaçôes, desenhos, restos dos processos de criação. A performatividade do registro explode quando William Forsythe e Volker Kuchelmeister, em 1994, transformam esse resto em obra de dança com seu CDroom Improvisation Technologies (multimídia interativa): a toll for the analytical eye. Trata-se de um software para estudo do movimento que é organizado em quatro grandes categorias: escrita, reorganização, linhas e adicionais a serem exploradas a partir de tarefas para a resoluçáo de caminhos e trajetórias propostas. Nos registros do software, os traços acompanham o presente da execução motora, coexistindo assim a imagem do corpo se movendo e o rastro desenhado do movimento, que se configura como parte da obra ${ }^{5}$.

No campo da dança, no Brasil, são muitos os artistas interessados em registros de movimento. Seja esse interesse no âmbito pedagógico, como percebemos na tese de Gabriela Christófaro (2018), que nos apresenta os registros de movimento de aulas de Marilene Martins, do Trans-Forma Centro de Dança Contemporânea, seja ele de artistas da cena da dança. A improvisadora Dudude Herrmann publica, em 2011, o Caderno de Notaçôes: a poética do movimento no espaço de fora, obra que contém registros sob a forma de letra - textos reflexivos - referentes a quatro de seus cadernos de processos, dos anos 2003 e 2004. Márcia de Moraes desenha os solos da dançarina e coreógrafa Juliana Moraes, entre 2002 e 2005, e os disponibiliza na internet $^{6}$. A pesquisa de doutorado da dançarina e coreógrafa Thembi Rosa (2020), que problematiza a noção de arquivo, com base no estudo da inserção de registros de movimento nas mídias digitais, é outro ponto alto no que diz respeito ao estudo de registros de movimento associados a novas mídias digitais.

Desde o final do século XX, temos ainda forte impulso no processo de arquivamento e tratamento de registros de movimento dos processos de criação em dança sendo elaborados em vários países. Esse impulso pode ser visto 
no site Synchronous Object (2009) ${ }^{7}$, criado por William Forsythe, que é a primeira parte do Motion Bank, também coordenado por ele em parceria com Scott de Lahunta (2010-2013 - Fase 1) ${ }^{8}$. Ambos são plataformas digitais que objetivam o estudo compartilhado de modos processuais da prática coreográfica, com especial ênfase nas novas possibilidades de criação a partir dos registros efetuados e disponibilizados em plataformas digitais (Rosa; Falci, 2018). O Motion Bank, projeto de pesquisa codirigido por Florian Jenett e Scott de Lahunta, no âmbito da Mainz University of Applied Sciences, destaca-se por ser uma plataforma focada na notação e gravaçáo em tempo real a partir do diálogo com artistas coreógrafos - Debora Hay, Jonathan Burrows e Matteo Fargio, entre outros -, que viabiliza diversas possibilidades investigativas'. Para Thembi Rosa (2018, p. 6), essas são instâncias disponibilizadas para criar "redes de encontros interdisciplinares gerados para pensar, criar, propor e produzir formas de visualizaçóes da dança". Thembi Rosa, em parceria com Scott de Lahunta, iniciou no Brasil, em 2019, um desdobramento desse projeto: o Motion Bank Brasil. Assim, a dançarina colocou na agenda internacional os trabalhos de coreógrafas, como Dudude Herrmann, Dorothé Depeauw, Margo Assis, e dela mesma, que se envolveram na documentação digital, na notação e na visualização de características de suas obras de dança $a^{10}$. Na Universidade Nova de Lisboa, temos a Prof. ${ }^{a}$ Carla Montez Fernandes, com seu premiado projeto Black Box, uma plataforma colaborativa para documentar e analisar a composição de performances, interrelacionando os estudos da cena e a linguística cognitiva.

Sem pretender esgotar, com esse breve percurso, as práticas de documentação do movimento na dança, sua presença neste texto vai ao encontro da ideia de apresentar distintas formas de tratamento do registro, para que possamos concebê-lo como instância performativa. Com esses exemplos, podemos perceber que o ato de registrar passa tanto pela necessidade de representação do movimento, para viabilizar sua posterior execuçáo, quanto pela incorporaçáo e apropriaçáo do registro como parte da obra de dança e, ainda, pelo tratamento do registro como invenção (Rosa; Falci, 2018).

A pesquisa que realizei principiou da proposta de olhar os registros de movimentos atravessando sua condição não só de uma representação do movimento executado pelo ator-dançarino, do movimento criado pelo coreógrafo, ou de um registro como obra, como propôs Forsythe. Interessoume, para além disso, observar o registro, visando perceber como ele poderia 
me afetar em direção a outros movimentos. Sem trabalhar com recursos computacionais, como poderia ser feito por meio do Motion Bank, operei na proximidade da restância do movimento presente nos cadernos de processo de Ione de Medeiros, criados durante o espetáculo Aldebaran (2013), concebendo a observação como ato inventivo. Percebendo a associação entre a percepção visual e a percepçáo cinestésica, experimentei a leitura corpórea dos registros por intermédio da improvisação de movimentos ${ }^{11}$.

\section{Modos de Percorrer o Caminho da Pesquisa}

A pesquisa foi realizada mediante o estudo de registros do processo de criaçáo de Aldebaran, a partir da abordagem proposta pela crítica genética no campo teatral ${ }^{12}$, e utilizou como metodologia a leitura corpórea e o exercício de revisão da literatura. A chamada crítica genética, iniciada no campo da literatura na década de 1960, trata do estudo dos processos de criação também decorrente de registros efetivados durante a criaçáo das obras ${ }^{13}$. Importa dizer que fiz uma assessoria de movimento cênico, em 2012, somada à coordenação da pesquisa de preparação corporal para a cena junto à diretora Ione de Medeiros, o que me proporcionou intimidade com os artistas e com as nuances do processo. Os dados, oriundos da observaçáo e da posterior experiência corpórea dos registros de movimentos, sob a forma de desenho, foram imbricados a conceitos provenientes de campos fronteiriços, como as ciências cognitivas. Essa articulaçáo entre conceitos e movimentos deve-se ao meu desejo de perceber e conceber, pelo traço do desenho, da letra, e também daquilo que está na borda do registro, pensamentos sobre o corpo em processo de criação.

Experimentei a observação como invenção, realizando junto a ela uma leitura corpórea do movimento desenhado. Qualificar a observaçáo como inventiva consiste em considerar que nesse ato há razão e emoção entrelaçadas (Damásio, 1996) somadas à boa dose de imaginação, o que nos faz coincidir com o que Paul Valéry (2012) diz a respeito dos desenhos de Degas: "Observar é, em grande parte, imaginar o que esperamos ver". Inicialmente, busquei identificar quais registros me moviam em direção a outros movimentos e, ao sentir o que as imagens me pediam, efetuei a escolha daqueles que seriam experimentados em movimento do/no meu próprio corpo. Desse modo, não estudei os registros circunscrita a sistemas de análise, mas me deixei afetar pelos desenhos, pelo movimento que resta no traço. 
Então, a partir desse exercício de percepção visual e cinestésica, busquei compreender qual movimento o desenho me solicitava, me instigava e o que me gerava em termos reflexivos. Após experimentar com movimentos aquilo que via - o que chamo de leitura corpórea -, escrevia, sob a forma de letra, as sensaçóes e suspeiçóes acerca do estado do corpo naquele processo de criaçáo. Dancei o desenho, pensando sobre o corpo durante o próprio movimento e performando meu pensamento pelo exercício da escrita reflexiva. Assim, reiteramos o imprescindível entrelaçamento entre pensamentosentimento-ação - presente nos processos de experimentação inventiva passível de ocorrer nas pesquisas em artes.

A partir da ideia de tradução do desenho para o movimento dançado, exercitei uma espécie de traição ou de atualização do instante capturado pelo gesto da escrita do movimento. Essa experimentação metodológica esteve fortemente ancorada na consideraçáo de que há pensamento reflexivo no movimento, bem como na imagem, ainda que não seja, inicialmente, operado por palavras. Não é necessário destrinchar o corpo em partes, ao modo descartiano - pensamento/movimento/sentimento/razão/emoçáo -, para que se efetive uma leitura atenta da experiência poética do movimento. E, quando me refiro à leitura, solicito ao leitor que não a restrinja apenas aos órgãos da visão, pois lemos com todo o corpo. Coloquei em movimento o registro (Figura 1), por meio dessa observaçáo fortemente afetiva, o que me incluiu intencionalmente como sujeito criador daquilo que observava. Uma prática de pensamento em movimento que buscava a composição com restos, com vestígios.

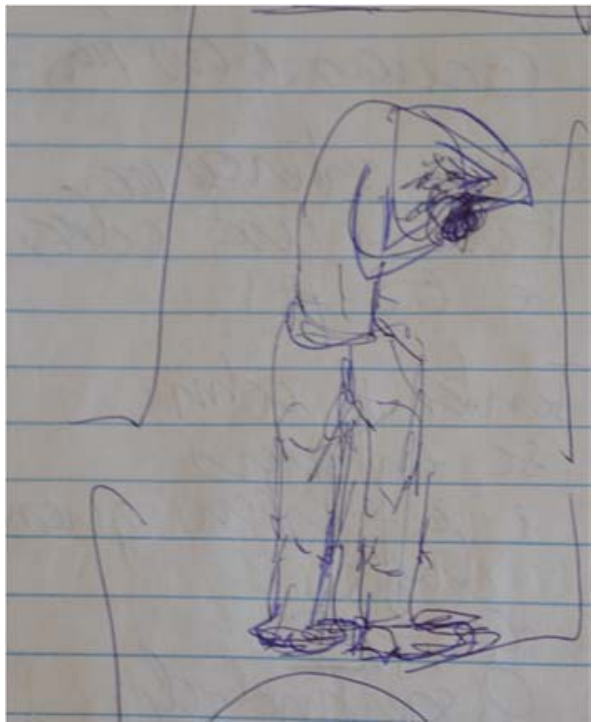

Figura 1 - Improvisação corporal para o espetáculo Aldebaran, 2012.

Fonte: Medeiros (2012). 
Experimento a flexão de tronco com mãos atrás da cabeça, joelhos flexionados, olhando para meus pés. Pausa. Solto o braço direito, o esquerdo. Pausa. Retomo o entrecruzar das mãos atrás da cabeça, no pescoço. Subitamente, levanto o tronco, olho a frente. Giro. Retomo a imagem inicial, a do desenho. Desmancho. Retomo. Desmancho lentamente... retomo rapidamente. Desmancho. Repetição. Repetição com variaçôes (Ribeiro, 2015).

O desenho, como nos diz Didi-Huberman (1998, p. 10), "abre pensamento", nos faz pensar rumo a diálogos com teorias e outras práticas. A performatividade dos registros implicou transformação em meu próprio corpo. Ainda que a experiência tenha se configurado como exercício de repetição com variaçóes, por via da imitação do movimento desenhado, seguida de improvisação, tratei de "refazer diferente" (Hissa, 2013, p. 125). Ao mover meu corpo, buscando corporificar o desenho, estudei a imagem, o traço do processo de criação ora vivido pelos artistas do Grupo Oficina Multimédia.

Isso posto, apresentarei, a seguir, imagens de Aldebaran, cuja montagem possibilitou a ocorrência dos desenhos dos movimentos estudados, associadas a relatos textuais sobre alguns fragmentos, constituindo uma breve reflexão do espetáculo. A seguir, desenvolverei a discussão em decorrência dos processos corporais da observação, da simulação e da imitação. Tais processos foram reconhecidos durante a experiência da pesquisa para chegar à proposta de corpos ressoantes, que permitem a percepção de sua qualidade constitutiva relacional.

\section{O Contexto do Movimento Desenhado: Aldebaran}

Os desenhos de movimentos estudados foram feitos durante os anos de 2011 a 2013, como parte da documentaçáo do processo de criaçáo de Aldebaran.

Aldebaran remete a esses tempos apoteóticos, em que as leis proliferaram e o politicamente correto se instalou como uma regra social, mas, paradoxalmente, nunca se viu tanto horror, tanta violência e tanta crueldade. Esta soma de desvios e arbitrariedades humanas desencadeou no planeta uma grande desordem que se estendeu para a natureza e para tudo que nos cerca (Medeiros, 2013, p. 1).

A partir de estudos sobre os monstros - desde a antiguidade, com os monstros marinhos, até os monstros contemporâneos, como guerras, matan- 
ças e crueldades do homem -, o grupo iniciou a criação do espetáculo com estudos práticos e teóricos. Do campo da literatura, encontros com Lisley Nascimento, autora da obra Da fabricação de monstros (2009) e professora da Universidade Federal de Minas Gerais (UFMG), marcaram os estudos teóricos para a cena do espetáculo em estudo. A ênfase no trabalho com o movimento, característico do Grupo, se fez ainda mais aguda e teve a colaboração de artistas como Mário Nascimento, coreógrafo e dançarino, Rosa Antuña, dançarina e atriz, e Gabriela Christófaro, professora da Licenciatura em Dança da UFMG e dançarina ${ }^{14}$.

Nesse percurso de criação, materiais e objetos - caixas de papeláo, papeláo, plástico bolha - fizeram parte das improvisaçôes de cenas desde o início, e tornaram-se cruciais no espetáculo, como se poderá notar a seguir nas imagens de cenas. Em Aldebaran, o objeto equipara-se, no que se refere à importância cênica, aos atores. Movimentam-se ambos pelo espaço, presentificando reveses, autoritarismos, golpes. O movimento cênico dos atores e objetos, associado às imagens em vídeo, desencadeia, ora no ritmo veloz dos grandes centros urbanos, ora na lentidão, metáforas cênicas de catástrofes, como guerras, queimadas, desastres.

Ao principiar da temática dos monstros e da investigaçáo do que seria um monstro na atualidade, a dramaturgia da cena apresentou um universo imagético no qual atores se hibridizam com objetos e compóem uma paisagem de micromovimentos, como podemos perceber na imagem a seguir (Figura 2), do fotógrafo Netun Lima. Nela, presentifica-se o objeto-papeláo que, pouco a pouco, vai ampliando seu movimento até ficar na posição vertical. Os atores que animam o papel não são vistos e a cena se constrói, minimalisticamente, em tons de terra ao som de pássaros. 

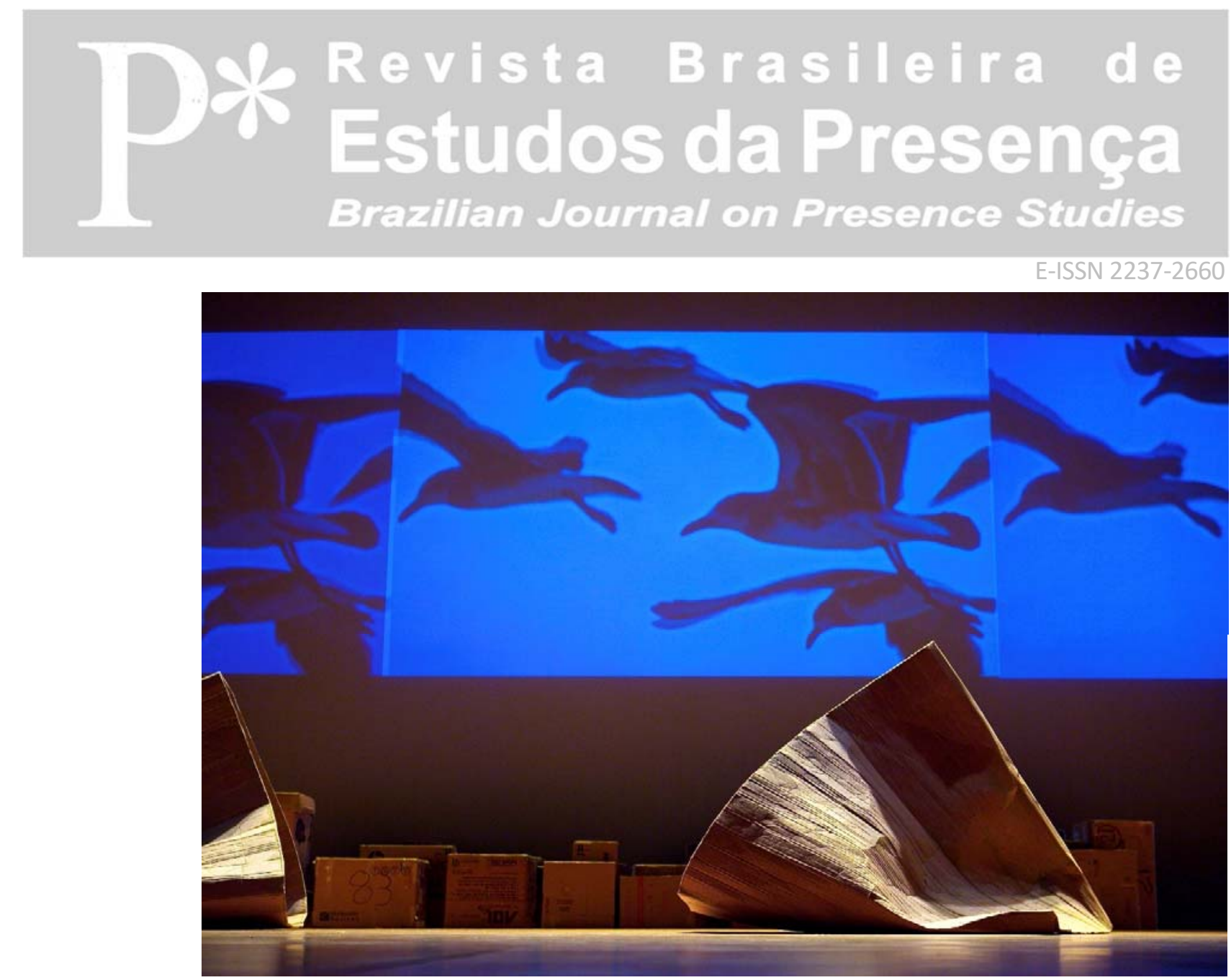

Figura 2 - Imagem de Aldebaran. Autor: fotógrafo Netun Lima, 2013. Fonte: Arquivo pessoal do Grupo.

O objeto nessa obra é prioritariamente feito de papeláo e plástico bolha. Caixas, esteiras, capas, fardos, todos esses tipos de papeláo operam no espaço-tempo em parceria com os atores. Animados, tais artefatos, por vezes, velam os corpos dos atores, fazendo com que eles, de táo próximos, desapareçam. O objeto torna-se um dispositivo que metamorfoseia os sujeitos em seres misteriosos - monstros. Ou podemos pensar que os atores se fundem ao objeto-papel, animando-o e sendo animados por ele.

Nas próximas imagens (Figura 3; Figura 4), também de Netun Lima, podemos inferir o ritmo veloz que toma conta da cena numa clara alusão à agitaçáo dos grandes centros. Atores e objetos correm e saltam pelo espaço, propiciando a sensação de pressa e de certo anulamento dos sujeitos que se misturam, em tom e em movimento, às caixas de papeláo. 

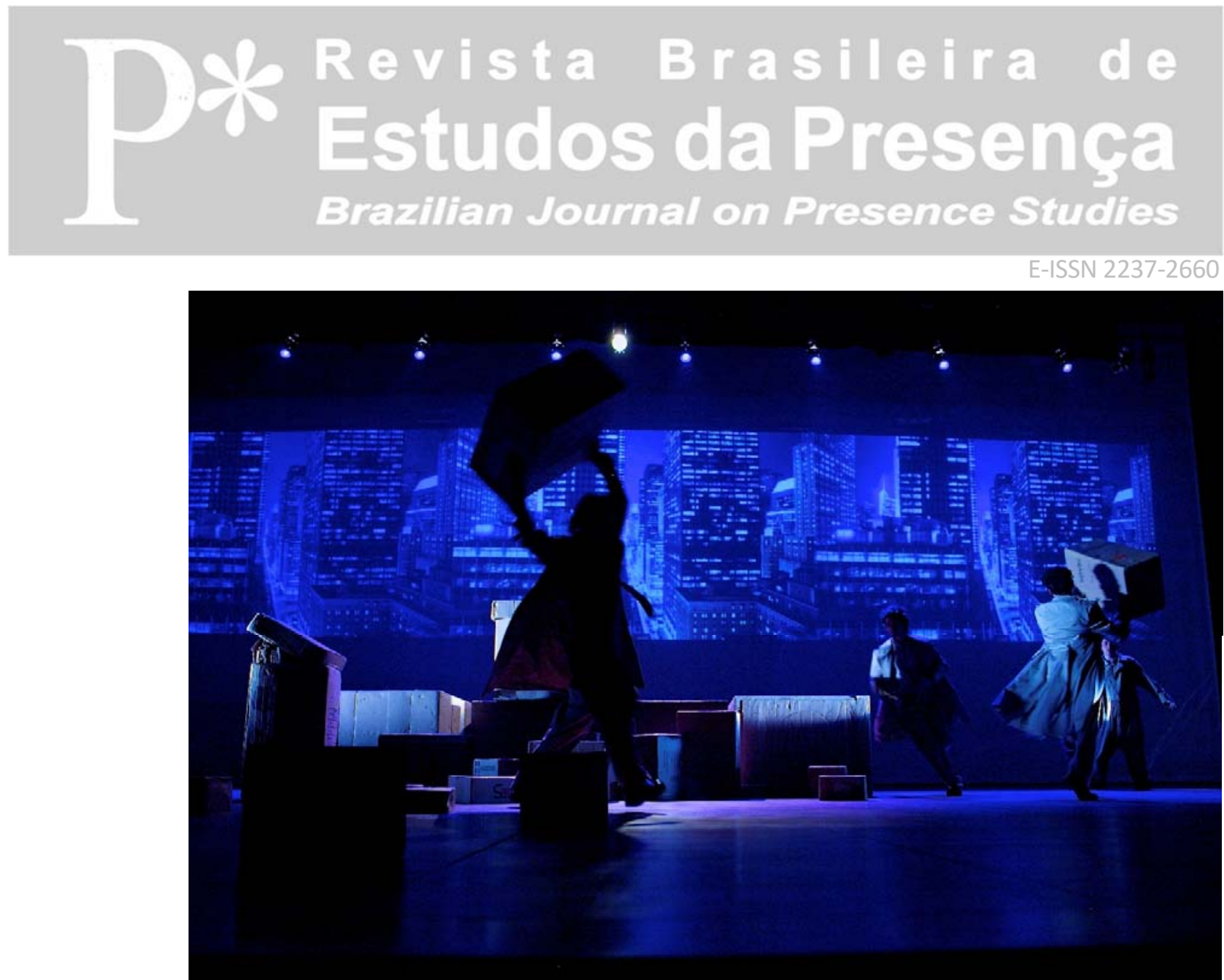

Figura 3 - Imagem de Aldebaran. Autor: fotógrafo Netun Lima, 2013. Fonte: Arquivo pessoal do Grupo.

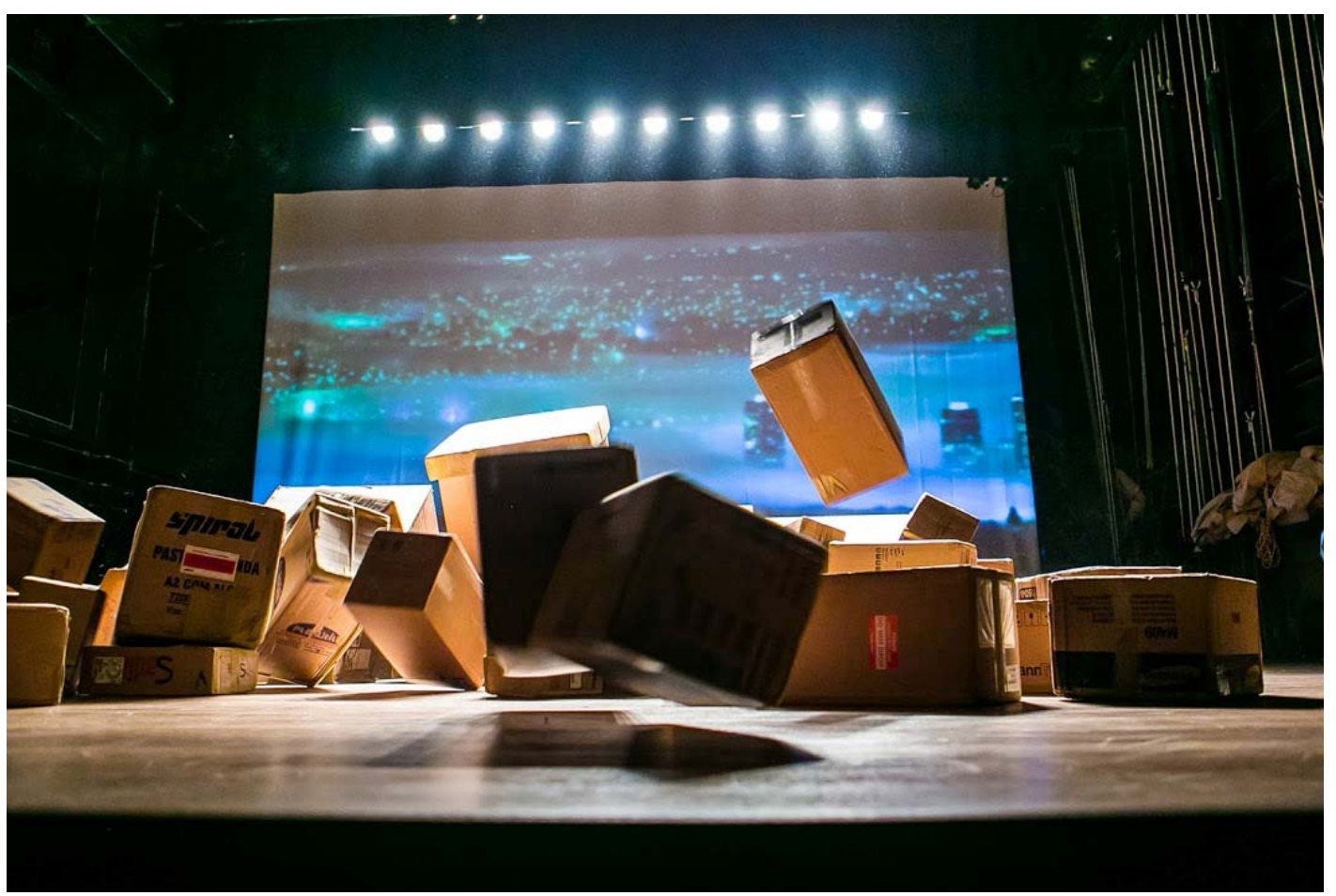

Figura 4 - Imagem de Aldebaran. Autor: fotógrafo Netun Lima, 2013. Fonte: Arquivo pessoal do Grupo.

Ao final da obra, a estrela Aldebaran, possuidora de brilho intenso, se aproxima, trazendo consigo uma promessa de paz e recomeço. Na cena, Aldebaran irrompe para salvar o planeta, resgatando da Terra aquilo que te- 


\section{nonot

mos de mais precioso, para caminharmos em direção à construção de um novo mundo.

Em oposição aos monstros surge Aldebaran, guardiã do universo, representando as forças do bem contra o mal. Estrela de altíssimo brilho, cinquenta vezes maior do que o sol, sua função é resgatar do planeta Terra tudo aquilo que foi considerado sagrado e precioso e com esses bens da humanidade reconstruir um mundo novo, em qualquer ponto distante do universo. Uma vez cumprida essa tarefa, restaria do antigo planeta apenas a memória de algo profundamente belo que se perdeu para sempre (Medeiros, 2013, p. 1).

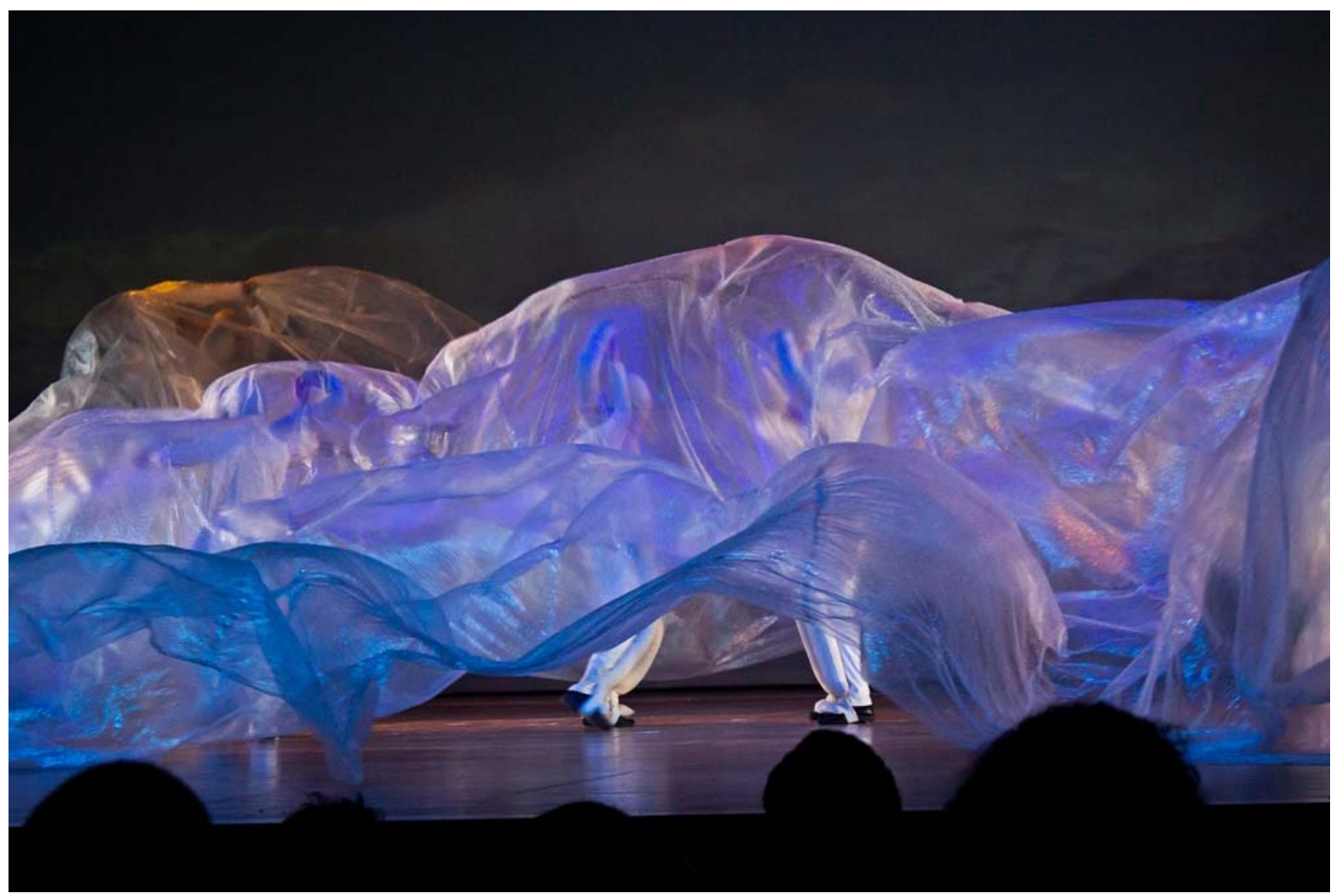

Figura 5 - Imagem de Aldebaran. Autor: fotógrafa Catarina Paulino, 2014. Fonte: Arquivo pessoal do Grupo.

Ao observarmos a foto anterior (Figura 5), vemos o imenso plásticobolha - imagem de nuvem, água, mistério - cobrindo o palco e, sob ele, bonecos, acoplados aos atores, caminhando. A impressão desejada é a de que esses seres poderiam criar um mundo sem guerras, desigualdades, crueldades, sem monstros.

O espetáculo finaliza com uma sequência de imagens de obras de arte, de artistas, de cientistas, de filósofos que marcaram a história da humanidade (Figura 6), deixando em evidência sua crença de que a valorização da cultura é o caminho para a construção de um novo modo de viver ${ }^{15}$. 

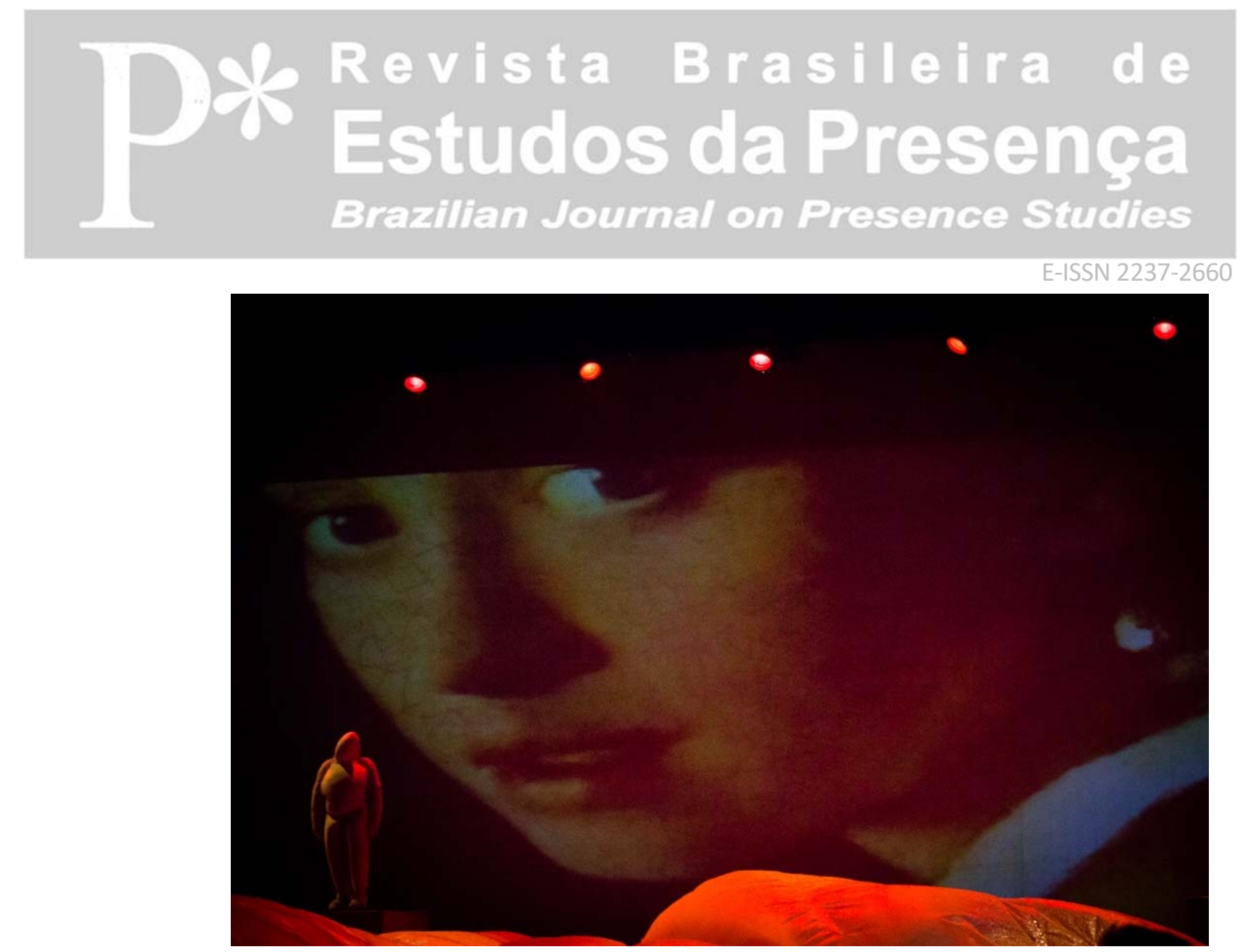

Figura 6 - Imagem de Aldebaran. Autor: fotógrafa Catarina Paulino, 2014.

Fonte: Arquivo pessoal do Grupo.

Os atores foram rigorosamente acompanhados no seu processo inventivo de movimentos para a cena. A diretora possui, desde 1977, o hábito de registrar toda a fase de montagem do espetáculo, o que inclui o treinamento rítmico corporal ${ }^{16}$, as improvisaçóes, os estudos teóricos. A escrita em cadernos de processo por Medeiros se sobressai devido à precisão de detalhes presentes nos registros daquilo que observa. A escrita composta por letra e desenho possibilitou-me pensar o corpo em processo. E o que marca esse corpo do processo de criação de Aldebaran? Quais seriam suas singularidades?

\section{Sobre o Corpo em Processo}

Refletir sobre o corpo em processo é, sobretudo, sublinhar sua condição de matéria movente em contínua invenção e transformação de si. $\mathrm{O}$ corpo que se constitui como espaço de entrecruzamentos é também texto e movimento que viabilizam o pensar.

Pensamento sobre corpo e corpo-pensamento trazem em si parcelas do mundo. Esse corpo, não objetificado pelo desenho, é marcado pelo traço que presentifica algo do movimento realizado no ensaio. Entrar em contato com os desenhos nos faz exercitar a memória em performance, movendo subjetividades ao observar, de modo inventivo, o registro na folha do caderno. 
Percebido pelo desenho, o corpo de quem se moveu no ensaio é contextualizado também pela borda do traço, por aquilo que está no papel para além do desenho. Há palavras que informam o contexto do ensaio, do treinamento e da improvisação. Assim, estudar a imagem registrada implicou também caminhar por suas margens, para abrir espaço para novas afecçóes provenientes de outros rastros do processo. Então, o corpo em açáo, desenhado, se fez corpo-mundo, corpo-processo de criação, um traço que porta histórias. O registro revelou o corpo-sujeito, e se mostrou avesso a análises que tenderiam para sua objetificação.

A potência de movimento que o desenho gesta me encaminhou para a invenção de outros movimentos. Optei por improvisar os desenhos, performando-os novamente. Olhar o desenho e sentir-me olhada por ele, à la DidiHuberman (1998), deu vazão a um processo de criação por afecção. Como o desenho me afeta? Afetar é verbo resultante da provocação que modifica o corpo e "o faz mover-se (afetar e ser afetado por outros corpos) e, do lado da mente, a faz pensar" (Chauí, 2011, p. 84) ${ }^{17}$. O que pode o desenho?

Inicialmente, senti-me levada a reproduzir o movimento observado, imitando-o. Uma imitação que encaminhou experimentaçôes motoras durante a improvisação. Experimentei o traço e sua espessura, respondendo a uma sensação de pertencimento. Durante a observação inventiva, somada à leitura corpórea, sentia-me parte daquilo que via. A imagem me pedia movimento, e parte desse movimento eu conhecia pelo que observava. Experimentei o reconhecimento de mim, de meus saberes decorrentes de minha trajetória de vida, no e pelo outro. Tomei consciência da existência de uma dimensão comum entre eu e aquele que fora desenhado (Figura 7).

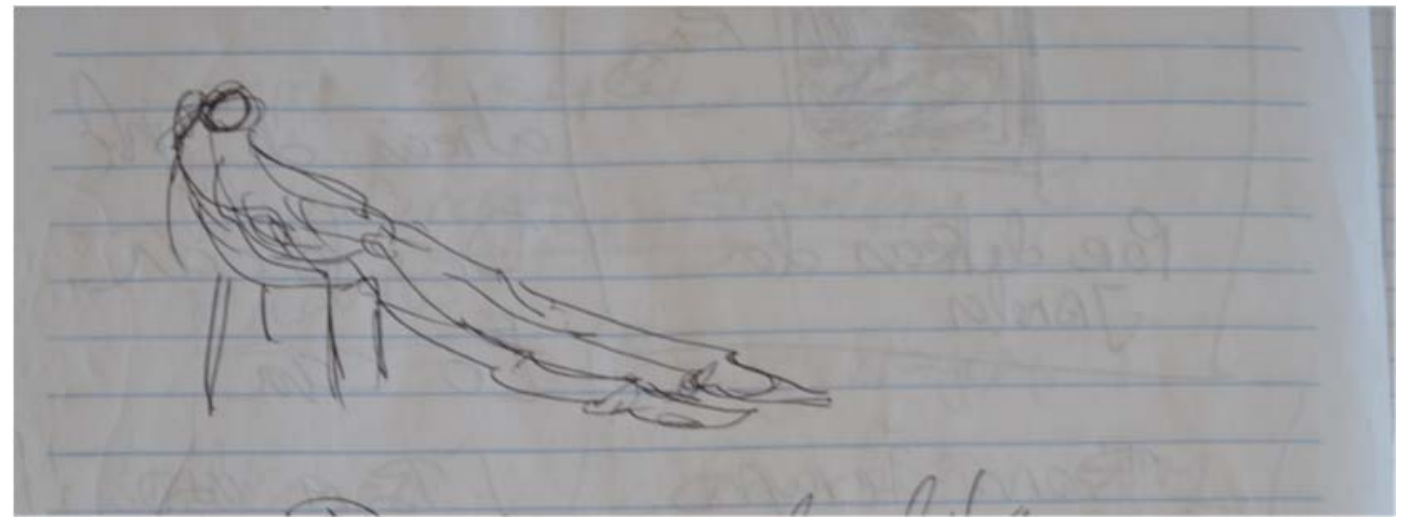

Figura 7 - Improvisação corporal para o espetáculo Aldebaran. Fonte: Medeiros (2012). 
Sento. Aos poucos vou escorregando na cadeira. Sigo o desenho. A cabeça pende à frente. Olho e vejo cansaço, corpo exausto de movimento. Deixo estar... apenas me movo internamente. Penso, sinto, penso-sinto, imagino. No externo: silêncio. Os pés que vejo me pedem movimento. Arrasto minhas plantas dos pés no chão alternando entre direita e esquerda. Acelero. Corro sentada. Caí. Aceleração. Interrupção (Ribeiro, 2015).

$\mathrm{O}$ que, em termos de processos corporais, viabilizava essa afecçáo? Meu corpo ressoa com o desenho, assim como pode ressoar na percepção de movimentos de outras pessoas? Ao vermos alguém bocejando, por exemplo, nosso corpo mapeia internamente essa ação - simula mentalmente o bocejo - e nos pomos a bocejar (Houzel, 2007). São processos de ressonância entre quem observa e quem é observado. Mas podemos pensar que, ao olhar o desenho, estaria meu corpo realizando-o internamente, ressoando com a imagem pictórica?

Sabemos que, quando observamos uma ação, nosso corpo a mapeia internamente no córtex cerebral, em função de nossas células multimodais, chamadas neurônios-espelho, descobertas por Rizzolatti, Fadiga, Fogassi e colaboradores (1996). Assim, podemos pensar que, quando fruo dança, teatro, obras de artes visuais, entre outras, internalizo aquilo que observo, trazendo para meu próprio corpo experiências de alteridade. Posso dizer que são experiências de alteridade, porque essa simulação parte da capacidade que temos de perceber intençóes e objetivos daquele cujo movimento observamos, o que adensa a ideia mesma de movimento e do próprio ato de observar.

Assim, durante a improvisação experimentada na leitura corpórea do registro, o desenho me pedia movimento. Foi essa sensação de afecção que me levou rumo à ação inventiva na improvisação: começava imitando, e, em seguida, imprimia ao movimento observado e praticado novas possibilidades expressivas. A percepção visual do registro se associava a uma percepção cinestésica dele em meu corpo.

A percepção, ao modo de Berthoz (2000), é uma ação exploratória, uma escolha que prediz, que lança hipóteses sobre o mundo, julgando a ação e antecipando suas consequências. Ainda que pensemos que estamos vendo o movimento, estamos também apreendendo o outro, aprendendo sobre ele, num exercício intersubjetivo. A aproximação eu-outro se dá por meio da simulação, processo que aciona trajetórias neurais concernentes ao movimento observado. É como se esse movimento ocorresse simultanea- 
mente em meu corpo, porém de modo não visível. Em 2008, apontamos a necessidade de se compreender que o movimento se inicia de modo náo perceptível àquele que o observa (Ribeiro; Teixeira, 2008). Podemos dizer que o movimento corporal é composto por uma parte visível e outra não visível, que se dá em nível cortical. Na simulaçáo do movimento observado ocorreria, portanto, a realizaçáo cortical desse movimento, ou seja, sua parte não visível.

Com essa afirmação, não estou atribuindo ao cérebro uma protagônica responsabilidade pelos modos de percepção, de maneira apartada do mundo. Seria impossível essa cisão entre cérebro e mundo, uma vez que o cérebro é corpo e o corpo se constitui na sua relaçáo de imbricação com o mundo: corpo-mundo. Csordas (1993) nos auxilia nessa ressalva quando distingue corpo e corporificação, afirmando que corpo é matéria biológica e a corporificaçáo é o modo de engajamento e presença do sujeito no mundo que se dá via experiência perceptiva. Essa compreensáo se afiniza com os estudos da cognição corporificada que compreendem a mente como corpo em contínua relaçáo com o mundo (Varela; Thompson; Rosch, 1993; Berthoz, 2000; 2004; 2006). É essa dimensão corporificada que nos interessa, objetivando o pensar sobre o corpo no processo de criação.

$\mathrm{Na}$ esteira desse pensamento, temos Gabriele Sofia (2009; 2012) que nos fala sobre a performance do espectador. Em sua pesquisa acerca da participação dos espectadores na cena teatral, ele retoma os estudos sobre os neurôniosespelho para pensar essa coconstituição da poiesis cênica, pensando em como a ação do artista da cena afeta aquele que a observa, que a frui. E Sofia vai adiante quando sugere que o ator propicia as condiçóes para acolher essa experiência performativa do espectador. Coincidindo com suas reflexóes, pensamos que a experiência de encontro com a obra de arte - seja espectador-ator(atriz); espectador-filme/vídeo; espectador-pintura/desenho/gravura - está fortemente ancorada em processos corporais de ressonância que estão, por sua vez, embebidos em culturas e subjetividades.

$\mathrm{Na}$ experiência da pesquisa aqui compartilhada, a visão foi explorada na sua imbricaçáo com a cinestesia e, a partir da prática consciente dessa multimodalidade sensorial, subjacente ao ato de improvisação, me aproximei das intençóes do ator/atriz performer do movimento registrado e daquele que desenhou seu movimento, pelo estudo do comportamento do traço. Como dissemos anteriormente, essa investigação motora iniciou-se 
pela imitação do desenho. A imitação, decorrente da já mencionada simulaçáo interna, constitui-se também como operador de ressonância eu-outro. Sublinho, assim, que o corpo traz em si processos - observação; simulação; imitação - que viabilizam a relação intersubjetiva por via da percepção. Essa possibilidade de trazer parcelas do movimento observado para meu próprio corpo evidencia a condição relacional entre corpo e mundo.

A improvisação, por meio de procedimentos como repetiçáo, aceleração, desaceleração, interrupçóes, possibilitou a composição provisória de escritas com o corpo a partir dos restos de um outro processo de criação: o de Aldebaran. Essa composiçáo, mobilizada pela leitura corpórea, foi possível devido ao exercício de perceber-me ressoando com o que observava e, especialmente, com as intençóes contidas no traço do desenho. Esse ressoar impulsionou a trajetória inventiva da percepção à ação.

Com Jeannerod (2008), podemos acrescentar que é justamente a consciência da intenção do movimento do outro que facilita a distinção eu/outro. Desse modo, podemos dizer que esses corpos ressoantes, que ressoam entre si por meio de uma atenção compartilhada no instante da experiência estética, não nos levam ao apagamento das subjetividades. Ao contrário, estar na experiência compartilhada, no coletivo, pode tornar mais forte a singularidade de cada sujeito. Observar o outro, ao observar o desenho de seu movimento, e compreendê-lo para além do traço, considerando seu contexto, não leva à fusão eu-outro. Isso porque essa internalização do outro em si demanda a autopercepção e viabiliza as condiçôes necessárias à expressão intencional: consciência corporal, capacidade de variação, capacidade de atualização de propostas motoras. A metáfora da ressonância refere-se, assim, à correspondência entre a ação observada e a ação executada. Como sua resultante, podemos dizer que ocorre um entrelaçamento entre perceber e agir e, também, entre eu e o outro. Compreendemos que essa ressonância faz parte dos processos de comunicação, interação e, também, da afeç̧ão sentida no encontro com o registro.

Possivelmente, devido ao contexto da improvisação corporal, a imitação gerou mais do que cópia e esse aspecto inventivo se deu como desdobramento da repetição nesse contexto. A apropriação corpórea do movimento desenhado, operada na improvisação, ocorreu mediante procedimentos compositivos já citados - repetição, aceleraçáo, desaceleração, interrupçôes - que incluíram também a fragmentação, o deslocamento do foco do 
movimento, mudanças de velocidade, de tamanho, variaçóes de tônus muscular, de direção, de movimento, alternância, superposição, sucessão, entre outros. Assim, coexistiam identidade e diferença (Derrida, 1991) na repetiçáo em diferentes contextos, o que promovia o deslocamento do sentido dos desenhos como registro. Portanto, tratei-os como instâncias performativas. Repetir para chegar ao diferente, esse foi o procedimento priorizado.

À pergunta que me fiz, questionando-me se estaria meu corpo ressoando com a imagem pictórica, responderia que sim. Gallese (2010), um dos pesquisadores envolvidos na descoberta dos neurônios-espelho, ao final da década de 1990, sugere que a resposta estética a obras de arte - pinturas e esculturas - está fundamentada na ativação de mecanismos de ressonância corporal, como a simulação motora. Apesar de o pesquisador dizer que essas simulaçóes se deram com imagens de movimentos de máos tentando agarrar um objeto, ou algo semelhante, ele sugere que pode haver simulação de imagens de movimentos realizados por outros efetores. Gallese acrescenta que estudos neurofisiológicos recentes demonstraram que, quando uma ação familiar é observada, ainda que não seja efetivada pela mão ou boca, ela também é mapeada no córtex motor do observador. Assim, a consciência de si, necessária para a percepçáo do outro, como dito anteriormente, somada ao repertório do observador, interfere na sua capacidade de interpretar o registro e criar a partir dele. Recorro novamente a Gallese (2018) quando diz que nossos cérebros possuem a capacidade de reconstruçáo de açóes a posteriori ao observar um movimento pintado ou desenhado. Ao olhar o desenho, imaginamos o corpo que o movimentou, o gesto de quem o registrou e sentimos o desenho em nosso corpo de tal modo que nos colocamos em movimento. Assim, pudemos perceber, na experiência de leitura corpórea, a teoria de ressonância dos neurônios-espelho. Compreendemos a experiência de ressonância como uma inter-relação entre observação, sentimento, imaginação e movimento.

A performatividade do registro deve-se tanto à sua potência de afetar quem o observa, ou à capacidade de o observador ser afetado durante a percepçáo do registro, quanto à capacidade de ter seu sentido deslocado na repetição com variação. Importa ressaltar que náo precisamos organizar essa afecção de forma linear, do desenho para o observador ou vice-versa. A afecção se dá pelo encontro que borra excessivas distinçóes temporais ao revelar 
algo do passado que será necessariamente atualizado no presente e reconfigurado em novas possibilidades de movimento.

O desenho se configura entáo entre dois corpos em movimento: aquele corpo que foi desenhado e o corpo que corporificará o desenho sob a forma de dança. Esse espaço-tempo entre permite que a ressonância se efetive pela observação, simulação e imitação inventiva do movimento. Pelo desenho, os corpos, de diferentes momentos e sujeitos, se encontram na imbricação de percepção visual e motora, como se o instante capturado pela mão que desenhou pusesse em conexão passado e futuro.

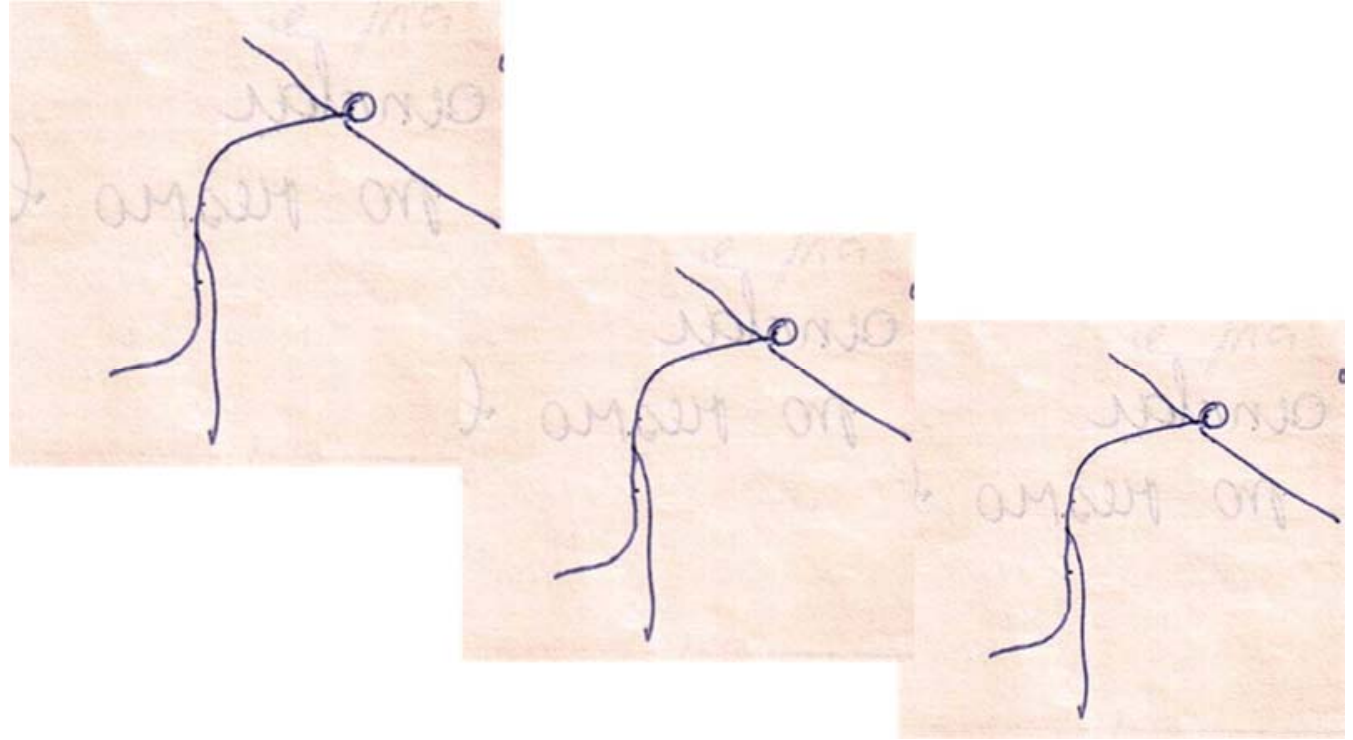

Figura 8 - Improvisaçáo corporal para o espetáculo Aldebaran. Fonte: Medeiros (2012).

O desenho-registro (Figura 8) opera como um terceiro corpo-entre, que, como nos aponta Cássio Hissa (2017, p. 18-19), “[...] não é um, mas são dois ou vários entrecortados. [...] O terceiro é a fronteira [...]”. No desenho, se atravessam o corpo desenhado, o gesto-corpo que desenha - presentificados no próprio desenho - e o corpo-sujeito que o observa e corporifica. Corpos de sujeitos-mundo que portam suas autorias de movimento. Lugar de fronteira, esse corpo-desenho permite o exercício de convivência entre as singularidades, por meio da assinatura pessoal dada ao movimento, associada àquilo que resta do outro. Supomos que a fronteira potencializa o comum que nos permite ressoar com o outro, operado pelas sensaçóes de pertencimento, reconhecimento e interaçáo. Mediado pela ressonância, o encontro possibilita também a atualização do próprio movimento como efeito da compreensão daquilo que de mim difere. 
O estado dos corpos imaginados e pensados, a partir do estudo dos registros do processo de criaçáo de Aldebaran, é de ressonância. Corpos ressoantes, corpos tecidos em e para relaçôes, sublinham a necessidade de se experimentar a alteridade. Perceber-me e perceber o outro em mim exigem ativação de processos corporais de ressonância. Pensar sobre corpos ressoantes é considerar que não há um solo, isolado, é também saber que a experiência atenta na observaçáo inventiva promove o entretecimento eu-outro. Somos sempre atravessados por outros. Disso decorre a consciência de que o saber de si implica aprender a perceber aquilo que é diferente.

\section{Consideraçóes Finais}

Estudar os registros de movimento construídos no processo de criação do espetáculo Aldebaran levou-me a conhecer modos diversos de registros de movimento, também chamados partituras, notaçóes, escrita de dança. $\mathrm{O}$ registro tem sido alçado a um status de invençáo por excelência, como podemos experimentar se acessarmos, por exemplo, a mencionada plataforma digital Motion Bank.

A investigação sobre processos de criação facultada pelo estudo críticointerpretativo de documentos primários, como diário de bordo, cadernos de processo, entre outros, faz parte da agenda dos pesquisadores de dança não apenas com o objetivo de preservação das obras, mas, principalmente, pela potência performativa dos diferentes registros de movimento. Ter experimentado essa performatividade, por meio da afecçáo resultante do contato com os desenhos, que me fez dançá-los e pensar sobre os processos corporais envolvidos nesse encontro entre o observador e o registro de movimento, me faz sugerir que a ressonância é condição para as interaçôes poéticas de constituição da cena de dança, de teatro, podendo ser considerada como operador corpóreo da fruiçáo.

Por isso, corpos ressoantes parecem ser imprescindíveis ao ato de criação compartilhado - que ocorre no encontro entre artista e espectador - e ao exercício da convivência táo caro à comunidade das artes da cena. Estar consciente da existência desses tipos de processos corporais, que nos levam ao entrelaçamento com o outro, pode sensibilizar-nos no que tange ao modo como vivenciamos as práticas coletivas, de maneira a fortalecermos tanto nossas singularidades, quanto a compreensão da importância daquilo que 
nos é comum. Perceber a condição relacional constitutiva desses corpos ressoantes confere-nos coragem para insistirmos na prática da coletividade.

$\mathrm{O}$ estudo dos registros de processos de criação, como instâncias mnemônicas performativas, no campo dos estudos corporais - na dança, no teatro - acessa memórias do processo e, igualmente, pode ser mobilizador de novas experiências inventivas nas artes. A improvisação corporal, somada à observação e à leitura corpórea de imagens-desenho, cria condiçóes, fundadas no movimento, para o exercício reflexivo sobre o corpo em processo de criação. A pesquisa realizada, aqui parcialmente compartilhada, faz-me ressaltar a importância de se efetivar alianças estéticas entre as mais diversas escritas que compóem nossas formas de criar leituras de mundo através da prática artística.

\section{Notas}

1 Pesquisa financiada pela FAPEMIG, por meio do Edital Demanda Universal, e constituída pelo estudo crítico-interpretativo de documentos processuais - cadernos de artista - acerca do corpo em processo durante as fases pertencentes à criação dos espetáculos As últimas flores do Jardim das Cerejeiras (2011); Play it Again +Dressur (2012) e Aldebaran (2013), do Grupo Oficcina Multimédia. "O presente trabalho foi realizado com apoio da Coordenação de Aperfeiçoamento de Pessoal de Nível Superior - Brasil (CAPES) - Código de Financiamento 001". Este trabalho foi realizado no âmbito do programa de Pósgraduação em Artes da Escola de Belas Artes da Universidade Federal de Minas Gerais.

2 Espetáculo do Grupo Oficcina Multimédia, estreado em 18 de abril de 2013, patrocinado pela Petrobrás/Ministério da Cultura. Disponível em: <https://www.youtube.com/watch?v=Ve_ZWIOfjf8>. Acesso em: 11dez. 2019.

3 Ione de Medeiros é musicista e diretora teatral do Grupo Oficcina Multimédia (BH) desde 1983. Disponível em: <http://oficcinamultimedia.com.br/v2/c/ogrupo/>. Acesso em 20 de nov. 2019.

4 Raoul-Auger Feuillet (1659 or 1660-1710) (Goff, 1995).

5 Disponível em: <http://www.niea.unsw.edu.au/research/publications/improvisationtechnologies-tool-analytical-dance-eye>. Acesso em: 20 jan. 2020.

6 Disponível em: <http://www.julianamoraes.art.br/Desenhos-de-Marcia-deMoraes>. Acesso em: 10 jan. 2020 
7 Disponível em: <https://synchronousobjects.osu.edu/media/inside.php>. Acesso em: 10 jan. 2020.

8 Disponível em: <http://motionbank.org/>. Acesso em: 03 jan. 2020.

9 Disponível em: <http://motionbank.org/>. Acesso em: 03 jan. 2020.

10 Disponível em:

$<$ http:/www.sdela.dds.nl/motionbank/brazillab2019/\#/mosys/grids/718d441bf9f0-4381-8850-80dc81b5d779>. Acesso em: 03 jan. 2020.

11 Este texto desenvolve a palestra REGISTROS para MOVIMENTOS: a observação como operador de invenção, apresentada no UFMG Talks, em dezembro de 2019, que compartilhou parte dos resultados da pesquisa $O$ corpo em processo: a performatividade do registro na gênese da cena.

12 A Genética teatral tem sido desenvolvida em diversos países, destacadamente França e Brasil, como se pode conhecer pela leitura da Revista Brasileira de Estudos da Presença, em seu volume 3, n. 2, publicada em 2013. Josette Féral, Jean-Marie Thomasseau, Almuth Grésillon, Marie-Madaleine Mervant-Roux, Silvia Fernandes e Luiz Marfus estão entre os autores que discutem, nesse número da revista, aspectos fundamentais acerca da crítica genética no campo teatral por meio de experiências associadas a estudos teóricos.

13 São vários os pesquisadores do campo das artes que se dedicam ao estudo dos processos de criação, o que pode ser verificado em obras como as de Fayga Ostroyer (2009), Cecília Salles (2004; 2008; 2010; 2017), Ângela Grando e José Cirillo (2009), além do dossiê da Revista Brasileira de Estudos da Presença v. 3, n. 2, de 2013.

14 Os atores do espetáculo Aldebaran, dirigido por Ione de Medeiros, foram Arthur Camargos, Diego Matos, Escandar Alcici Curi, Gabriel Corrêa, Henrique Mourão, Jhonathan Oliveira, Jonnatha Horta Fortes, Marco Vieira, Nicolás Bolívar e Sérgio Salomão, que se somaram à criação de bonecos com Daniel Herthel, à trilha sonora de Francisco César e à iluminação de Telma Fernandes. Para conferir partes do processo de trabalho do grupo durante a montagem, sugerimos o acesso ao link: <http://oficcinamultimedia.com.br/v2/espetaculos/aldebaran/>. Acesso em: 03 jan. 2020.

15 A apresentação completa do espetáculo, apresentado no Festival Internacional de Teatro de $\mathrm{BH}$ no Teatro Bradesco, em maio de 2014, está disponível em: $<$ https://youtu.be/1nlx6z53PSQ>. No minuto 1:01:53, pode-se ver as imagens finais com a citação de artistas, cientistas e filósofos. Para acesso a outras fotos do espetáculo, 
indicamos o link <http://www.focoincena.com.br/aldebaran?programa=true > . Acesso em: 03 jan. 2020.

16 A Rítmica Corporal é uma prática de treinamento corporal desenvolvida por Ione de Medeiros com forte influência das práticas pedagógicas de Edgar Willems e de Jaques Dalcroze.

17 Vale lembrar que nesta reflexão não se pretende separar corpo e mente, mas sim reiterar que são dimensões distintas da mesma matéria.

\section{Referências}

BENESH, Rudolf; BENESH, Joan. An Introduction in Benesh Notation. London: Adam \& Charles Black, 1956.

BERTHOZ, Alain. The Brain's Sense of Movement. Cambridge: Harvard University Press, 2000.

BERTHOZ, Alain; JORLAND, Gérard (Org.). L'Empathie. Paris: Odile Jacob, 2004.

BERTHOZ, Alain; PETIT, Jean-Luc. Phénoménologie et physiologie de l'action. Paris: Odile Jacob, 2006.

CHAUÍ, Marilena. Desejo, paixão e ação na ética de Espinosa. São Paulo: Companhia das Letras, 2011.

CHRISTÓFARO, Gabriela Córdova. Convivência e alteridade no processo de conhecimento em dança: a abordagem de Marilene Martins no Trans-Forma Centro de Dança Contemporânea. 2018. Tese (Doutorado em Artes) - Programa de Pós-graduação em Artes, Universidade Federal de Minas Gerais, Belo Horizonte, 2018.

CSORDAS, Thomas J. Somatic Modes of Attention. Cultural Anthropology, v. 8, n. 2, p. 135-156, 1993.

DAMÁSIO, Antonio R. O Erro de Descartes: emoção, razão e o cérebro humano. Tradução de Dora Vicente e Georgina Segurado. São Paulo: Companhia das Letras, 1996.

DERRIDA, Jacques. Limited inc. Campinas: Papirus, 1991.

DIDI-HUBERMAN, George. O que vemos, o que nos olha. São Paulo: Editora 34, 1998.

FISCHER-LICHTE, Erika. The transformative power of performance: a new aesthetics. New York: Taylor and Francis, 2008. 
GALLESE, Vittorio. Mirror neurons and Art. 2010. Disponível em: $<$ https://www.researchgate.net/publication/284661288_Mirror_neurons_and_art >. Acesso em: 20 jun. 2017.

GALLESE, Vittorio et al. Behavioral and autonomic responses to real and digital reproductions of works of art. Progress in Brain Research, v. 237, p. 201-221, 2018.

GOFF, Moira. The art of dancing, demonstrated by characters and figures: French and English sources for court and theatre dance, 1700-1750. Electronic British Library Journal, London, 1995. Disponível em: <https://www.bl.uk/eblj/1995 articles/pdf/article14.pdf>. Acesso em: 20 nov. 2019.

GRANDO, Ângela; CIRILLO, José (Org.). Arqueologias da criação: Estudos sobre o processo de criação. Belo Horizonte: C/Arte, 2009.

GROTOWSKI, Jerzy. Conferenza a Liège, Cirque Divers, 2 gennaio 1986. In: RICHARDS, Thomas. Al Lavoro con Grotowski Sulle Azioni Fisiche. Milano: Ubulibri, 1993. P. 85-90.

HERRMANN, Maria de Lourdes Tavares. Caderno de Notaçóes: A Poética do Movimento no espaço de Fora. Belo Horizonte: Edição da Autora, 2011.

HISSA, Cássio Eduardo Viana. Entrenotas: compreensóes de pesquisa. Belo Horizonte: Editora UFMG, 2013.

HISSA, Cássio Eduardo Viana. Entre. In: SILVA, Maria Ivonete Santos; MOREIRA, Maria Elisa Rodrigues (Org.). Literatura: espaço fronteiriço. Colatina; Chicago: Clock-Book, 2017. P. 11-28.

HOUZEL, Herculano S. Por que o bocejo é contagioso? São Paulo: Zahar, 2007.

JEANNEROD, Marc. Motor Cognition: what actions tell the self. New York: Oxford University Press, 2008.

MEDEIROS, Ione de. Caderno de processo 2E. 2012.

MEDEIROS, Ione de. Programa do espetáculo Aldebaran. 2013.

MORAES, Juliana Martins Rodrigues. O conceito de coreografia em transformação. Urdimento - Revista de Estudos em Artes Cênicas, Florianópolis, v. 1, n. 34, 2019.

NASCIMENTO, Lyslei; JEHA, Julio (Org.). Da fabricação de monstros. Belo Horizonte: Editora da UFMG, 2009. 
OSTROWER, Fayga. Criatividade e processos de criação. Petrópolis: Editora Vozes, 2009.

RIBEIRO, Mônica Medeiros. Caderno de processo. Arquivo pessoal da autora. 2015.

RIBEIRO, Mônica Medeiros; TEIXEIRA, Antônio Lúcio. Aprender uma coreografia: contribuiçóes das neurociências para a dança. Neurociências, v. 4, n. 4, 2008.

RIZZOLATTI, Giacomo et al. Premotor cortex and the recognition of motor actions. Brain research. Cognitive brain research, v. 3, n. 2, p. 131-141, 1996.

ROSA, Thembi. Dança: arquivos como invençôes. 2020. Tese (Doutorado em Artes) - Programa de Pós-graduação em Artes, Universidade Federal de Minas Gerais, Belo Horizonte, 2020.

ROSA, Thembi; FALCI, Carlos. Registers as inventions: body, dance, memory and digital medias. In: INTERNATIONAL CONFERENCE ON MOVEMENT AND COMPUTING, MOCO, 5., 2018, Genoa. Proceedings... Genoa, Italy, 2018.

SALLES, Cecília Almeida. Gesto Inacabado: processo de criação artística. São Paulo: FAPESP: Annablume, 2004.

SALLES, Cecília Almeida. Redes da criação: construção da obra de arte. São Paulo: Editor Horizonte, 2008.

SALLES, Cecília de Almeida. Arquivos de Criação: Arte e Curadoria. São Paulo: Editora Horizonte, 2010.

SALLES, Cecília de Almeida. Processos de Criação em Grupo. Diálogos. São Paulo: Estação das Letras e Cores, 2017.

SOFIA, Gabriele (Org.). Dialoghi tra teatro e neuroscienze. Roma: Edizioni Alegre, 2009.

SOFIA, Gabriele. Teatro e Neurociência: da intenção dilatada à experiência performativa do espectador. Revista Brasileira de Estudos da Presença, Porto Alegre, v. 2, n. 1, p. 93-122, jan./jun. 2012.

VALÉRY, Paul. Degas dança desenho. São Paulo: Cosac Naify, 2012.

VARELA, Francisco J.; THOMPSON, Evan; ROSCH, Eleanor. The embodied Mind: cognitive science and human experience. Cambridge; London: MIT Press, 1993. 
Mônica Medeiros Ribeiro é professora do Departamento de Artes Cênicas e da Pós-graduação em Artes da Escola de Belas Artes da Universidade Federal de Minas Gerais.

ORCID: http://orcid.org/0000-0002-5625-6115

E-mail: monicaribeiro@yahoo.com

Este texto inédito também se encontra publicado em inglês neste número do periódico.

Recebido em 30 de janeiro de 2020

Aceito em 01 de junho de 2020

Editor-responsável: Gilberto Icle

Este é um artigo de acesso aberto distribuído sob os termos de uma Licença Creative Commons Atribuição 4.0 Internacional. Disponível em: <http://creativecom mons.org/licenses/by/4.0>. 